\title{
Implikasi Putusan Mahkamah Konstitusi Nomor 68/PUU-XV/2017 Terkait Pembatalan Sanksi Pidana Terhadap Jaksa Penuntut Umum Dalam Penanganan Perkara Anak Berhadapan Dengan Hukum
}

\author{
Harry Rachmat \\ harryrachmat84@gmail.com \\ Universitas Airlangga
}

\begin{abstract}
The method used in this study is normative juridical research (legal research), using the approach to the problem of statutory approaches (conceptual approach), conceptual approach (conceptual approach). The problems in this study are: What is the Constitutional Court's consideration in the cancellation of criminal sanctions against public prosecutors in handling child cases dealing with the law and Is the effort to prevent misuse of the authority of the Public Prosecutor who handles child cases dealing with the law related to cancellation Article 99 Law Number 11 of 2012 concerning the Criminal Justice System for Children after the Decision of the Constitutional Court Number 68 / PUU-XV / 2017. The imposition of criminal sanctions on the Public Prosecutor due to not carrying out the obligation to issue children from detention as stipulated in Article 34 of Act Number 11 of 2012 concerning the Child Criminal Justice System (SPPA) is a mistake in establishing the law, because the violation is an administrative violation rather than is a criminal act. Based on the experience of the author as the Public Prosecutor, the existence of criminal sanctions against prosecutors in handling child cases has a bad impact on prosecutors, where many prosecutors refuse to be appointed to handle child cases. With the status of prosecutors as civil servants as mandated in the Prosecutor's Law, making the prosecutor's profession must also submit to the ASN Law. Therefore, indirectly, the Prosecutor must implement the AUPB in carrying out his duties. In order to realize prosecutors who have high personal integrity and discipline to carry out law enforcement duties in order to realize justice and truth, a prosecutor's code of ethics is issued as stated in the Republic of Indonesia Attorney General's Regulation Number Per-014 / A / JA / 11/2012 Prosecutor's Code of Conduct. Based on the provisions of Article 12 of the Prosecutor's Code of Conduct, prosecutors who are proven to have committed violations have been subjected to administrative action without waiving criminal provisions and disciplinary conditions based on the disciplinary regulations of civil servants if there are provisions violated.
\end{abstract}

Keywords: Criminal Sanctions; Public Prosecutors; Child Protection.

\begin{abstract}
Abstrak
Metode yang digunakan dalam penelitian ini adalah penelitian yuridis normatif (legal research), dengan menggunakan pendekatan masalahpendekatan perundang-undangan (statute approach), pendekatan konseptual (conceptual approach). Permasalahan dalam penelitian ini adalah : Apa pertimbangan Mahkamah Konstitusi dalam pembatalan sanksi pidana terhadap jaksa penuntut umum dalam penanganan perkara anak berhadapan dengan hukum dan Apakah upaya pencegahan penyalahgunaan kewenangan Jaksa Penuntut Umum yang menangani perkara anak berhadapan dengan hukum terkait dengan pembatalan Pasal 99 Undang-undang Nomor 11 Tahun 2012 tentang Sistem Peradilan Pidana Anak pasca Putusan Mahkamah Konstitusi Nomor 68/PUU$\mathrm{XV} / 2017 . P e n j a t u h a n$ sanksi pidana terhadap Jaksa Penuntut Umum dikarenakan tidak melakukan kewajiban mengeluarkan anak dari tahanan sebagaimana diatur dalam Pasal 34 Undang-undang Nomor 11 Tahun 2012 tentang Sistem Peradilan Pidana Anak (SPPA) merupakan suatu kekeliruan pembentuk Undang-undang, karena Pelanggaran tersebut merupakan pelanggaran administratif bukan merupakan suatu perbuatan pidana. Berdasarkan pengalaman penulis sebagai Jaksa Penuntut
\end{abstract}


Umum, adanya sanksi pidana terhadap jaksa dalam penanganan perkara anak berdampak buruk bagi kalangan jaksa dimana banyak jaksa menolak jika ditunjuk untuk menangani perkara anak. Dengan status jaksa sebagai PNS sebagaimana diamanatkan dalam UU Kejaksaan, membuat profesi jaksa harus tunduk pula kepada UU ASN. Oleh karena itu secara tidak langsung, Jaksa wajib menerapkan AUPB dalam melaksanakan tugas-tugasnya. Dalam rangka mewujudkan jaksa yang memiliki integritas kepribadian serta disiplin tinggi guna melaksanakan tugas penegakan hukum dalam rangka mewujudkan keadilan dan kebenaran, maka dikeluarkanlah kode etik perilaku jaksa sebagaimana tertuang dalam Peraturan Jaksa Agung Republik Indonesia Nomor Per - 014/A/JA/11/2012 Tentang Kode Perilaku Jaksa. Berdasarkan ketentuan Pasal 12 Kode Perilaku Jaksa, Jaksa yang terbukti melakukan pelanggaran dijatuhi tindakan administratif dengan tidak mengesampingkan ketentuan pidana dan hukuman disiplin berdasakan peraturan disiplin pegawai negeri sipil apabila atas perbuatan tersebut terdapat ketentuan yang dilanggar.

Kata Kunci: Sanksi Pidana; Jaksa Penuntut Umum; Perlindungan Anak.

\section{Pendahuluan}

Kebijakan pembentuk UU No. 11 Tahun 2012 tentang Sistem Peradilan Pidana Anak (SPPA) lebih berorientasi pada perlindungan pelaku (anak), namun mengesampingkan perlindungan bagi penegak hukum dan pejabat peradilan ketika menjalankan tugas dan wewenangnya sehingga pembentuk UU SPPA tidak menganut ide keseimbangan, keselarasan dan keserasian sehingga materi muatan dalam ketentuan tersebut tidak mencerminkan asas keadilan. Berdasarkan hal tersebut, Jaksa Agung Muda Tindak Pidana Umum, Noor Rachmad mengajukan gugatan uji materi Undang-Undang Nomor 11 Tahun 2012 tentang Sistem Peradilan Pidana Anak ke Mahkamah Konstitusi. Pasal yang diuji adalah Pasal 99 yang mengatur ancaman pidana bagi jaksa yang tidak melepaskan masa penahanan anak lebih dari lima hari. Pasal tersebut sangat berpotensi mengkriminalisasi dan mengusik independensi jaksa dalam menjalankan tugasnya. Sebagaimana ketentuan pidana anak, masa penahanan pidana anak adalah lima hari dan bisa diperpanjang lima hari lagi selama masa pra penuntutan. Kemudian jika ada kelalaian, maka ada sanksi pidananya. Hal ini berpotensi memberikan tekanan terhadap independensi jaksa dalam menjalankan tugas. Terhadap gugatan tersebut, Mahkamah Konstitusi akhirnya mengabulkan gugatan JAMPIDUM Noor Rachmad terkait uji materi Pasal 99 Undang-undang Nomor 11 Tahun 2012 tentang Sistem Peradilan Pidana Anak. Majelis Hakim Mahkamah Konstitusi di dalam salah satu pertimbangannya menyatakan bahwa ketentuan Pasal 99 tidaklah mempunyai ketentuan hukum 
yang mengikat. Ancaman pidana sebagaimana dimaksud merupakan suatu bentuk kriminalisasi terhadap pelanggaran administratif dalam penyelenggaraan sistem peradilan pidana anak. Setelah dikabulkannya gugatan uji materi Pasal 99 UndangUndang Nomor 11 Tahun 2012 memberikan angin segar kepada jaksa dalam menangani perkara anak. Dikabulkannya uji materi tersebut menghindarkan jaksa dari tekanan dan ketakutan akan kriminalisasi. Oleh karena itu dalam penelitian ini penulis ingin mengetahui apa pertimbangan Mahkamah Konstitusi dalam pembatalan sanksi pidana terhadap jaksa penuntut umum dalam penanganan perkara anak berhadapan dengan hukum dan Apakah upaya pencegahan penyalahgunaan kewenangan Jaksa Penuntut Umum yang menangani perkara anak berhadapan dengan hukum terkait dengan pembatalan Pasal 99 Undang-undang Nomor 11 Tahun 2012 tentang Sistem Peradilan Pidana Anak pasca Putusan Mahkamah Konstitusi Nomor 68/PUU-XV/2017.

\section{Pertimbangan Hakim Putusan Mahkamah Konstitusi Nomor 68/PUU- $\mathrm{XV} / 2017$.}

Dalam pertimbangan putusannya Mahkamah Konstitusi menyebutkan, Sistem Peradilan Pidana Anak (SPPA) adalah keseluruhan proses penyelesaian perkara Anak yang berhadapan dengan hukum, mulai tahap penyelidikan sampai dengan tahap pembimbingan setelah menjalani pidana [vide Pasal 1 angka 1 UU SPPA]. Dalam SPPA, penuntut umum merupakan salah satu pejabat khusus dalam proses SPPA. Pasal 99 UU 11/2012 mengatur mengenai ancaman pidana bagi penuntut umum apabila dengan sengaja tidak melaksanakan kewajiban mengeluarkan anak dari tahanan setelah dilakukan perpanjangan waktu penahanan. Terhadap ancaman pidana tersebut, Mahkamah, dalam Putusan Mahkamah Konstitusi Nomor 110/PUU-X/2012, bertanggal 28 Maret 2013, memberikan pertimbangan sebagai berikut:

"Pasal 96, Pasal 100, dan Pasal 101 UU 11/2012 yang menentukan ancaman pidana kepada pejabat khusus dalam penyelenggaraan SPPA, yaitu hakim, pejabat pengadilan, penyidik, dan penuntut umum, menurut Mahkamah, bukan saja tidak merumuskan ketentuan-ketentuan konstitusional mengenai kemerdekaan kekuasaan kehakiman dan independensi pejabat khusus yang 
terkait (hakim, penuntut umum, dan penyidik anak), yakni memberikan jaminan hukum bagi penyelenggaraan peradilan yang merdeka, tetapi lebih dari itu juga telah melakukan kriminalisasi terhadap pelanggaran administratif dalam penyelenggaraan SPPA yang tentu memberikan dampak negatif terhadap pejabat-pejabat khusus yang menyelenggarakan SPPA. Dampak negatif tersebut adalah dampak psikologis yang tidak perlu, yakni berupa ketakutan dan kekhawatiran dalam penyelenggaraan tugas dalam mengadili suatu perkara. Hal demikian menimbulkan ketidakpastian hukum dan ketidakadilan yang berarti bertentangan dengan Pasal 28D ayat (1) UUD 1945 dan kontra produktif dengan maksud untuk menyelenggarakan SPPA dengan diversinya secara efektif dan efisien dalam rangka keadilan restoratif."

Setelah memeriksa secara cermat norma undang-undang yang dimohonkan para Pemohon a quo ternyata merupakan satu kesatuan yang saling berkorelasi yang tidak dapat dipisahkan dengan norma undang-undang yang telah diputuskan oleh Mahkamah sebagaimana tertuang dalam Putusan Mahkamah Konstitusi Nomor 110/PUU-X/2012, bertanggal 28 Maret 2013, yang merupakan satu kesatuan dalam SPPA yang di dalamnya mengandung adanya sifat khusus dari keseluruhan proses dalam penyelesaian perkara anak yang berhadapan dengan hukum, mulai tahap penyelidikan sampai tahap pembimbingan setelah menjalani pindana [vide Pasal 1 angka 1 UU SPPA]. Oleh karena itu dengan pertimbangan sebagaimana tersebut di atas tidaklah tepat bagi Mahkamah apabila memperlakukan pejabat yang terlibat dalam proses SPPA tersebut, termasuk dalam tindakan yang berkaitan dengan penahanan dalam perkara anak dalam hal ini jaksa/penuntut umum, dibedakan perlakuannya dengan hakim. Pertimbangan Mahkamah tersebut tidak terlepas dari pertimbangan yang didasarkan pada keharusan adanya sinergitas seluruh komponen penegak hukum yang tergabung dalam SPPA yang mempunyai sifat khusus, akan tetapi bukan berarti Mahkamah membenarkan alasan independensi dalam pengertian yang universal di dalam menerima dalil-dalil para Pemohon a quo. Dengan demikian penting ditegaskan bahwa sekalipun Mahkamah telah menyatakan pasal yang dimohonkan para Pemohon a quo inkonstitusional, hal itu tidak berarti memperbolehkan pejabat yang melakukan tugas untuk mengeluarkan tahanan anak dari RUTAN melanggar batas waktu yang telah ditentukan, sebab hal demikian sama halnya dengan sengaja merampas kemerdekaan seseorang. 
Dengan kata lain, kesengajaan tidak mengeluarkan tahanan anak pada waktunya tidak menghilangkan hak setiap orang yang dirugikan atas adanya tindakan yang disengaja oleh setiap pejabat termasuk di dalamnya penegak hukum atas adanya perampasan kemerdekaan untuk dapat mempersoalkan secara hukum tindakan tersebut berdasarkan ketentuan Pasal 333 ayat (1) KUHP yang menyatakan, "Barang siapa dengan sengaja dan dengan melawan hukum merampas kemerdekaan seseorang, atau meneruskan perampasan kemerdekaan yang demikian, diancam dengan pidana penjara paling lama delapan tahun".

\section{Analisa Putusan Mahkamah konstitusi Nomor 68/PUU-XV/2017}

Sebagaimana Putusan Mahkamah Konstitusi Nomor 68/PUU-XV/2017 terdapat analisis hukum yang dikemukan oleh saksi ahli Romli Atmasasmita, Analisis hukum atas ketentuan Pasal 99 Jo. Pasal 34 ayat (3) UU RI Nomor 11 Tahun 2012 yang dijelaskan oleh saksi ahli menjelaskan hal-hal sebagai berikut: ${ }^{1}$

1. Undang-undang SPPA adalah undang-undang tentang sistem bukan undangundang tentang proses peradilan anak; dua hal yang berbeda karena pengertian sistem adalah an organized set of ideas or theories orparticular way of doing (Oxford Advanced Learner Dictionary, OxfordUniversity Press, 2010, p.1516). Sedangkan proses, adalah a series ofthings that are done in order to achieve a particular result (Oxford AdvancedLearner Dictionary,-Oxford University Press, 2010, p. 1168). Sistem, adalah perangkat unsur yang secara teratur saling berkaitan sehingga membentuksuatu totalitas. sedangkan proses adalah, suatu rangkaian tindakan atau pembuatan ataupengolahan yang menghasilkan produk. SubstansiUU SPPA, merupakan proses bukan sistem sebagaimana yang deskripsiKBI dan Kamus Bahasa lnggeris Oxford. Proses dalam pandangan sayamerupakan langkah nyata (action) untuk mencapai tujuan dalam konteks perlindungan anak sejak pembinaan, peringatan, penyelidikan, diversisampai pada penuntutan dan pemeriksaan sidang pengadilan. Sedangkansistem 
peradilan anak seharusnya keterkaitan berbagai unsur yangmerupakan totalitas mengenai perlindungan anak. Keterkaitan unsur-unsur dimaksud di dalam UU SPPA tidak tergambar dengan jelas karena proses yang diatur di dalamnya lebih menitikberatkan pada perlindungannya daripada penghukumannya sekalipun digunakan istilah peradilan pidana yang sejatinya tidak terdapat unsur penghukuman atau penjeraan di dalam UU SPPA tersebut;

2. Keterangan pemerintah mengenai keikutsertaan peranan kejaksaan dalamhal penuntutan pidana dalam proses peradilan pidana khusus untuk "anakyang berhadapan dengan hukum", justru berbanding terbalik dengan idedasar diperlukannya perubahan paradigma menempatkan anak yangberhadapan dengan hukum sebagai objek -bukan punishment ke subjekperlakuan (treatment). Dengan demikian keikutsertaan jaksa penuntutmerupakan penempatan yang keliru di dalam mencapai tujuan perlindungandan perlakuan bukan penghukuman. Kekeliruan tersebut kemudian diwujudkan dengan menempatkan jaksa penuntut sebagai objek penghukuman (punishment) yang kemudian dijadikan alasan pengajuan permohonan uji materiel pemohon ke Mahkamah Konstitusi RI;

3. Ketentuan Pasal 99 UU SPPA yang merujuk pada ketentuan Pasal 34 UU SPPA, merupakan ketentuan sanksi pidana terhadap seorang penuntut yang melanggar KEWAJIBAN tidak segera mengeluarkan tahanan anak dari Lapas dengan ancaman pidana paling lama 2 (dua) tahun. PembentukUU SPPA tidak dapat membedakan antara kewajiban (obligation) yangbersifat compliance), dan larangan (prohibition) yang bersifat imperativedengan tujuan pemaksaan (enforcement);

4. Sanksi yang sejalan dengan tujuan kepatuhan (compliance) terhadapkewajiban adalah sanksi administrative bukan sanksi pidana; sedangkansanksi yang sejalan dengan tujuan pemaksaan adalah sanksi pidana.Kekeliruan memahami perbedaan mendasar atas kedua pengertiantersebut mengakibatkan kerugian baik secara materiel maupun immaterialhak konstitusional pemohon (Persatuan Jaksa Indonesia) sehinggaketentuan Pasal 99 juncto Pasal 34 ayat (3) UU 
SPPA bertentangan denganPasal 28D ayat (1) UUD 1945, hak setiap orang atas pengakuan, jaminan,perlindungan, dan kepastian hukum yang adil serta perlakuan yang sama dihadapan hukum;

5. Lembaga Kejaksaan secara normative berdasarkan Pasal 24 ayat (3) UUD 1945 termasuk badan-badan lain yang fungsinya berkaitan dengan kekuasaan kehakiman, dan telah diatur di dalam UU Nomor 16 Tahun 2004 tentang Kejaksaan Republik Indonesia, dan secara inklusif, Lembaga kejaksaan adalah bagian dari kekuasaan kehakiman yang merdeka di dalam melaksanakan fungsi penuntutan;

6. Karakter kekuasaan yang merdeka yang dimiliki oleh Mahkamah Agung dan jajaran pengadilan di bawahnya serta kejaksaan yang merupakan salah satu bagian kekuasaan kehakiman tidak dapat diganggu gugat oleh siapapun termasuk kekuasaan eksekutif dan legislative in casu dengan cara apapun termasuk peraturan perundang-undangan yang berlaku. Salah satu praktik pembentukan perundang-undangan yang telah melegalkan instrusi terhadap kekuasaan kehakiman yang merdeka adalah UU SPPA 2012 yang antara lain memidana jaksa penuntut jika dengan sengaja melanggar ketentuan Pasal 34 UU SPPA 2012, dengan ancaman pidana paling lama 2 (dua) tahun. Ahli memahami benar keraguan dan ketidak pastian hukum yang dapat memberikan jaminan perlindungan atas pelaksanaan tugas penuntutan dalam kasus pidana anak atau anak yang berhadapan dengan hukum;

7. Dasar rujukan Putusan MK RI Nomor 110 Tahun 2012 sebagaimana dikutip dalam Permohonan Uji Materi oleh Pemohon merupakan yurisprudensi yang patut dipatuhi oleh Majelis Mahkamah Konstitusi RI dalam hal perkara yang sama dengan objek uji materi oleh pemohon yang masih berada di dalam lingkup kekuasaan kehakiman berdasarkan Pasal 24 UUD 1945. Lembaga kejaksaan dalam konteks Putusan MKRI Nomor 110 Tahun 2012 memiliki hak konstitusional yang sama dengan jabatan Hakim sehingga sungguhsungguh tidak terjadi perlakuan hukum yang tidak sama dihadapan hukum terhadap seluruh institusi penegak hukum di dalam melaksanakan tugas dan 
wewenangnya berdasarkan UU SPPA 2012.

Salah satu pertimbangan hakim yang mengabulkan permohonan para pemohon adalah: ${ }^{2}$ Pasal 96, Pasal 100, dan Pasal 101 UU 11/2012 yang menentukan ancaman pidana kepada pejabat khusus dalam penyelenggaraan SPPA, yaitu hakim, pejabat pengadilan, penyidik, dan penuntut umum, menurut Mahkamah, bukan saja tidak merumuskan ketentuan-ketentuan konstitusional mengenai kemerdekaan kekuasaan kehakiman dan independensi pejabat khusus yang terkait (hakim, penuntut umum, dan penyidik anak), yaitu memberikan suatu jaminan hukum bagi penyelenggaraan peradilan yang merdeka, tetapi lebih dari itu juga telah melakukan kriminalisasi terhadap pelanggaran administratif dalam penyelenggaraan SPPA yang tentu memberikan dampak negatif terhadap pejabat-pejabat khusus yang menyelenggarakan SPPA. Dampak negatif tersebut adalah dampak psikologis yang tidak perlu, yakni berupa ketakutan dan kekhawatiran dalam penyelenggaraan tugas dalam mengadili suatu perkara. Hal demikian menimbulkan ketidakpastian hukum dan ketidakadilan yang berarti bertentangan dengan Pasal 28D ayat (1) UUD 1945 dan kontra produktif dengan maksud untuk menyelenggarakan SPPA dengan diversinya secara efektif dan efisien dalam rangka keadilan restoratif.

Tidak hanya itu, berdasarkan pengalaman penulis sebagai Jaksa Penuntut Umum, adanya sanksi pidana terhadap jaksa dalam penanganan perkara anak berdampak buruk bagi kalangan jaksa. Banyak jaksa yang menghindar bahkan ketakutan dalam menangani perkara anak. Kebanyakan jaksa menolak jika ditunjuk untuk menangani perkara anak. Mereka merasa ketakutan dan merasa tertekan dalam proses penanganan perkara anak. Ancaman pidana dalam Pasal 99 Undangundang Perlindungan Anak merupakan suatu momok yang menakutkan bagi jaksa. Oleh karenanya, dengan adanya putusan Mahkamah Konstitusi Nomor 68/ PUU-XV/2017 yang membatalkan sanksi pidana dalam Pasal 99 Undang-undang Perlindungan Anak disambut baik oleh kalangan Jaksa Penuntut Umum. Meskipun sudah tidak ada lagi ancaman pidana terhadap Jaksa Penuntut Umum tidak akan 
mengurangi profesionalitas jaksa dalam penanganan perkara anak. Tanpa adanya intervensi dari luar, tuntutan profesionalitas sudah tertanaman dalam diri jaksa.

\section{Asas-asas Umum Pemerintahan Yang Baik sebagai Pedoman Jaksa Penuntut Umum Dalam Penanganan Perkara}

Istilah asas dalam Asas-asas Umum Pemerintahan yang Baik, atau AUPB, menurut pendapat Bachsan Mustafa dimaksudkan sebagai 'asas hukum', adalah suatu asas yang dijadika suatu dasar kaidah hukum. Asas hukum adalah asas yang menjadi alasan pembentukan kaidah-kaidah hukum, termasuk juga kaidah hukum tata pemerintahan. Kaidah atau norma adalah ketentuan-ketentuan tentang bagaimana seharusnya manusia bertingkah laku dan bergaul dengan manusia lainnya. Ketentuan tentang tingkah laku dalam hubungan hukum dalam pembentukannya,sekaligus penerapannya, didasarkan pada asas-asas hukum yang diberlakukan. Perlakuan asas hukum dalam lapangan hukum tata pemerintahan sangat diperlukan, mengingat kekuasaan aparatur pemerintah memiliki wewenang yang istimewa, lebih-lebih di dalam rangka penyelenggaraan kesejahteraan dan kepentingan umum dalam fungsinya sebagai bestuurszorg. ${ }^{3}$ Penjelasan atas Pasal 1 angka 1 menyatakan bahwa yang dimaksud dengan urusan pemerintahan adalah kegiatan yang bersifat eksekutif. Jika kita mendasarkan pada definisi Badan atau Pejabat Tata Usaha Negara di atas, maka aparat pemerintah dari tertinggi sampai dengan terendah mengemban 2 (dua) fungsi, yaitu: ${ }^{4}$

1. Fungsi memerintah (bestuursfunctie). Apabila fungsi memerintah (bestuursfunctie) tidak dilaksanakan, maka roda pemerintahan akan macet;

2. Fungsi pelayanan (vervolgens functie). Fungsi pelayanan adalah fungsi penunjang, kalau tidak dilaksanakan maka akan sulit menyejahterakan masyarakat.

Pasal 10 Undang Undang Nomor 30 Tahun 30014 tentang Administrasi

\footnotetext{
${ }^{3}$ Faried Ali, Hukum Tata Pemerintahan Heteronom dan Otonom (Refika Aditama 2012).[124].

${ }^{4}$ Cekli Setya Pratiwi, Penjelasan HukumAsas-Asas Umum Pemerintahan yang Baik(AUPB) (Judicial Sector Support Program 2016).[36].
} 
Pemerintahan menguraikan ruag lingkup AUPB yang berlaku dalam administrasi pemerintahan. Asas Umum Pemerintahan yang Baik yang dimaksud meliputi asas: ${ }^{5}$

1. Kepastian hukum. asas kepastian hukum merupakan asas dalam negara hukumyang mengutamakan landasan ketentuan peraturan perundangundangan, kepatutan, keajegan, dan keadilan dalam setiap kebijakan penyelenggaraan pemerintahan;

2. Kemanfaatan. asas kemanfaatan maksudnya manfaat yang harus diperhatikansecara seimbang antara: (1) kepentingan individu yang satu dengan kepentingan individu yang lain; (2) kepentingan individu dengan masyarakat; (3) kepentingan Warga Masyarakat dan masyarakat asing; (4) kepentingan kelompok masyarakatyang satu dan kepentingan kelompok masyarakat yang lain; (5) kepentingan pemerintah dengan Warga Masyarakat; (6) kepentingan generasi yang sekarangdan kepentingan generasi mendatang; (7) kepentingan manusia dan ekosistemnya; (8) kepentingan pria dan wanita.

3. Ketidakberpihakan. asas ketidakberpihakan adalah asas yang mewajibkan Badan dan/atau Pejabat Pemerintahan dalam menetapkan dan/atau melakukan Keputusan dan/atau Tindakan dengan mempertimbangkan kepentingan para pihak secara keseluruhan dan tidak diskriminatif.

4. Kecermatan. asas kecermatan dimaksudkan sebagai asas yang mengandung artibahwa suatu Keputusan dan/atau Tindakan harus didasarkan pada informasi dandokumen yang lengkap untuk mendukung legalitas penetapan dan/ataupelaksanaan Keputusan dan/atau Tindakan sehingga Keputusan dan/atau Tindakanyang bersangkutan dipersiapkan dengan cermat sebelum Keputusan dan/atau Tindakan tersebut ditetapkan dan/atau dilakukan;

5. Tidak menyalahgunakan kewenangan. asas tidak menyalahgunakan kewenanganadalah asas yang mewajibkan setiap Badan dan/atau Pejabat Pemerintahan tidakmenggunakan kewenangannya untuk kepentingan

${ }^{5}$ Muhamad Azhar, Relevansi Asas-Asas Umum Pemerintahan Yang Baik DalamSistem Penyelenggaraan Administrasi Negara (2015) Edisi 08 No. 2 Jurnal Notarius. 
pribadi atau kepentingan yanglain dan tidak sesuai dengan tujuan pemberian kewenangan tersebut, tidak melampaui, tidak menyalahgunakan, dan/atau tidak mencampuradukkan kewenangan;

6. Keterbukaan. asas keterbukaan adalah asas yang melayani masyarakat untuk mendapatkan akses dan memperoleh informasi yang benar, jujur, dan tidak diskriminatif dalam penyelenggaraan pemerintahan dengan tetap memperhatikan perlindungan atas hak asasi pribadi, golongan, dan rahasia negara;

7. Kepentingan umum. asas kepentingan umum adalah asas yang mendahulukankesejahteraan dan kemanfaatan umum dengan cara yang aspiratif, akomodatif,selektif, dan tidak diskriminatif;

8. Pelayanan yang baik. asas pelayanan yang baik dimaksudkan sebagai asas yangmemberikan pelayanan yang tepat waktu, prosedur dan biaya yang jelas, sesuaidengan standar pelayanan, dan ketentuan peraturan perundangundangan.

AUPB dapat dijadikan landasan atau pedoman bagi aparat pemerintah dalam menjalankan tugasnya, sekaligus sebagai alat uji bagi lembaga peradilan dalam menilai tindakan pemerintah ketika ada gugatan dari ohak lain yang dirasakan merugikannya. Dengan kata lain, AAUPB secara teoritis sangat penting dalam mewujudkanpemerintahan yang bersih, berwibawa, dan berkualitas baik di pusat maupun di daerah.Secara yuridis, cerminan pemerintah yang demikian dapat dilihat dari produk hukumyang ditetapkannya, seperti dalam wujud perizinan daerah yang berwawasan lingkungan hidup.

Sebagai salah satu Aparatur Sipil Negara (ASN), tentunya Jaksa harus menerapkan AUPB. Pengaturan mengenai profesi jaksa utamanya diatur dalam Undang-undang No. 16 Tahun 2004 tentang Kejaksaan (UU Kejaksaan) serta peraturan-peraturan turunannya. Dalam Pasal 9 ayat (1) UU Kejaksaan disebutkan bahwa salah satu syarat menjadi jaksa adalah Pegawai Negeri Sipil (PNS). Pegawai Negeri Sipil termasuk dalam lingkup Aparatur Sipil Negara (ASN) yang diatur dalam Undang-undang No. 15 Tahun 2014 tentang Aparatur Sipil Negara (UU 
ASN). Dengan status jaksa sebagai PNS sebagaimana diamanatkan dalam UU Kejaksaan, membuat profesi jaksa harus tunduk pula kepada UU ASN. Oleh karena itu secara tidak langsung, Jaksa wajib menerapkan AUPB dalam melaksanakan tugas-tugasnya.

\section{Peraturan Jaksa Agung Nomor: 014/JA/11/2012 Tentang Kode Etik Perilaku Jaksa}

Profesi jaksa adalah sebuah profesi yang sangat penting dalam penegakan hukum peradilan, dalam mentapkan posisi dan peranan kejaksaan, disamping adanya peraturan perundang-undangan yang mendasari dirii dari wewenangnya, dirasakan pula perlunya memiliki suatu doktrin demi mendorong serta menjamin terlaksananya secara mantap darma baktinya kejaksaan yang akan menjiwai sikap dan perilaku warganya dalam meraih cita-cita luhurnya. Jaksa Agung mengeluarkan kode etik prilaku jaksa sebagaimana tertuang dalam Peraturan Jaksa Agung Republik Indonesia (PERJA) Nomor Per-014/A/JA/11/2012 Tentang Kode Perilaku Jaksa. Didalam menjalankan tugas dan kewenangannya, telah diatur juga mengenai larangan-larangan terhadap jaksa sebagaimana diatur dalam Pasal 7 PERJA Nomor Per-014/A/JA/11/2012 menyebutkan:

(1) Dalam melaksanakan tugas Profesi Jaksa dilarang:

a. memberikan atau menjanjikan sesuatu yang dapat memberika keuntungan pribadi secara langsung maupun tidak langsung bagi diri sendiri maupun orang lain dengan menggunakan nama atau cara apapun;

b. meminta dan/atau menerima hadiah dan/atau keuntungan dalam bentuk apapun dari siapapun yang memiliki kepentingan baik langsung maupun tidak langsung;

c. menangani perkara yang mempunyai kepentingan pribadi atau keluarga, atau finansial secara langsung maupun tidak langsung;

d. melakukan permufakatan secara melawan hukum dengan para pihak yang terkait dalam penanganan perkara;

e. memberikan perintah yang bertentangan dengan norma hukum yang berlaku;

f. merekayasa fakta-fakta hukum dalam penanganan perkara;

g. menggunakan kewenangannya untuk melakukan penekanan secara fisik dan/ atau psikis; dan

h. menggunakan barang bukti dan alat bukti yang patut diduga telah direkayasa atau diubah atau dipercaya telah didapatkan melalui cara-cara yang melanggar hukum; 
(2) Jaksa wajib melarang keluarganya meminta dan/atau menerima hadiah atau keuntungan dalam bentuk apapun dari siapapun yang memiliki kepentingan baik langsung maupun tidak langsung dalam pelaksanaan tugas Profesi Jaksa.

Berdasarkan ketentuan Pasal 12 Kode Perilaku Jaksa, Jaksa yang terbukti melakukan pelanggaran dijatuhitindakanadministratifdengantidakmengesampingkan ketentuan pidana dan hukuman disiplin berdasakan peraturan disiplin pegawai negeri sipil apabila atas perbuatan tersebut terdapat ketentuan yang dilanggar. Dengan adanya Kode Perilaku Jaksa, penulis beranggapan bahwa apa yang terdapat dalam Undang-Undang Sistem Peradila Pidana Anak khususnya Pasal 99 UU No. 11 Tahun 2012 yang berisi tentang ketentuan pidana terhadap Jaksa Penuntut Umum yang tidak melaksanakan kewajibannya sebagaimana diatur dalam Pasal 34 ayat (3) tidak perlu diberlakukan. Profesionalisme jaksa dalam penanganan perkara anak berhadapan dengan hukum dapat tetap diawasi melalui instrumen kode etik perilaku jaksa sebagaimana tertuang dalam Peraturan Jaksa Agung Republik Indonesia Nomor Per - 014/A/JA/11/2012 Tentang Kode Perilaku Jaksa.

Instrumen pengawasan terhadap penyalahgunaan kewenangan oleh Jaksa penuntut Umum selain itu juga dapat menggunakan KUHP, yaitu Pasal 333 ayat (1) KUHP yang menyatakan, "Barang siapa dengan sengaja dan dengan melawan hukum merampas kemerdekaan seseorang, atau meneruskan perampasan kemerdekaan yang demikian, diancam dengan pidana penjara paling lama delapan tahun".

\section{Kesimpulan}

Pemberian sanksi pidana kepada Jaksa Penuntut Umum dalam Pasal 99 UU Perlindungan Anak menurut Mahkamah Konstitusi bertentangan dengan UndangUndang Dasar RI Tahun 1945 karena sejalan dengan putusan MK sebelumnya nomor 110/PUU-X/2012 Tanggal 28 Maret 2013 menyebutkan Pasal 96, Pasal 100, dan Pasal 101 UU 11/2012 yang menentukan ancaman pidana kepada pejabat khusus dalam penyelenggaraan SPPA, yaitu hakim, pejabat pengadilan, penyidik, dan penuntut umum, menurut Mahkamah, bukan saja tidak merumuskan ketentuanketentuan konstitusional mengenai kemerdekaan kekuasaan kehakiman dan 
independensi pejabat khusus yang terkait (hakim, penuntut umum, dan penyidik anak), yaitu memberikan suatu jaminan hukum bagi penyelenggaraan peradilan yang merdeka, tetapi lebih dari itu juga telah melakukan kriminalisasi terhadap pelanggaran administratif dalam penyelenggaraan SPPA yang tentu memberikan dampak negatif terhadap pejabat-pejabat khusus yang menyelenggarakan SPPA. Dampak negatif tersebut adalah dampak psikologis yang tidak perlu, yakni berupa ketakutan dan kekhawatiran dalam penyelenggaraan tugas dalam mengadili suatu perkara. Hal demikian menimbulkan ketidakpastian hukum dan ketidakadilan yang berarti bertentangan dengan Pasal 28D ayat (1) UUD 1945 dan kontra produktif dengan maksud untuk menyelenggarakan SPPA dengan diversinya secara efektif dan efisien dalam rangka keadilan restoratif tidak satupun memenuhi pertimbanganpertimbangan dalam merumuskan sanksi pidana. Oleh karena itu Mahkamah konstitusi berpendapat ketentuan dalam Pasal 99 sebagaimana diajukan oleh Jaksa Agung Muda Tindak Pidana Umum juga bertentangan dengan UUD RI Tahun 1945, sebagaiman putusan MK nomor 110/PUU-X/2012 tanggal 28 Maret 2013. Pelanggaran tersebut merupakan pelanggaran administratif bukan merupakan suatu perbuatan pidana. Ancaman pidana terhadap perbuatan pelanggaran yang bersifat administratif merupakan tanggungjawab bersama dengan lembaga pemasyarakatan dalam hal penahanan seorang anak yang berhadapandengan hukum sangatlah tidak tepat dan error in iuris karena sanksi administratif merupakan konsekuensi logis pertama yang harus didahulukan dari sanksi pidana. Sanksi pidana hanya diberlakukan jika sanksi administratif tidak efektif. Sanksi administratif merupakan primum remedium sedangkan sanksi pidana merupakan ultimum remedium.

Berdasarkan pengalaman penulis sebagai Jaksa Penuntut Umum, adanya sanksi pidana terhadap jaksa dalam penanganan perkara anak berdampak buruk bagi kalangan jaksa. Banyak jaksa yang menghindar bahkan ketakutan dalam menangani perkara anak. Kebanyakan jaksa menolak jika ditunjuk untuk menangani perkara anak. Dengan status jaksa sebagai PNS sebagaimana diamanatkan dalam UU Kejaksaan, membuat profesi jaksa harus tunduk pula kepada UU ASN. Oleh karena itu secara tidak langsung, Jaksa wajib menerapkan AUPB dalam melaksanakan 
tugas-tugasnya. Dalam rangka mewujudkan jaksa yang memiliki integritas kepribadian serta disiplin tinggi guna melaksanakan tugas penegakan hukum dalam rangka mewujudkan keadilan dan kebenaran, maka dikeluarkanlah kode etik perilaku jaksa sebagaimana tertuang dalam Peraturan Jaksa Agung Republik Indonesia Nomor Per-014/A/JA/11/2012 Tentang Kode Perilaku Jaksa.Berdasarkan ketentuan Pasal 12 Kode Perilaku Jaksa, Jaksa yang terbukti melakukan pelanggaran dijatuhi tindakan administratif dengan tidak mengesampingkan ketentuan pidana dan hukuman disiplin berdasakan peraturan disiplin pegawai negeri sipil apabila atas perbuatan tersebut terdapat ketentuan yang dilanggar. Instrumen pengawasan terhadap penyalahgunaan kewenangan oleh Jaksa penuntut Umum selain itu juga dapat menggunakan KUHP, yaitu Pasal 333 ayat (1) KUHP yang menyatakan, "Barang siapa dengan sengaja dan dengan melawan hukum merampas kemerdekaan seseorang, atau meneruskan perampasan kemerdekaan yang demikian, diancam dengan pidana penjara paling lama delapan tahun”.

\section{Daftar Bacaan}

\section{Buku}

Faried Ali, 'Hukum Tata Pemerintahan Heteronom dan Otonom', (Refika Aditama 2012).

Cekli Setya Pratiwi, 'Penjelasan Hukum Asas-Asas Umum Pemerintahan yang $\operatorname{Baik}(A U P B)$ ’ (Judicial Sector Support Program 2016).

Muhamad Azhar, Relevansi Asas-Asas Umum Pemerintahan Yang Baik Dalam Sistem Penyelenggaraan Administrasi Negara (Jurnal Notarius 2015).

\section{Keputusan}

Putusan Mahkamah Konstitusi Nomor 68/PUUX-V/2017.

HOW TO CITE: Harry Rachmat, 'Implikasi Putusan Mahkamah Konstitusi Nomor 68/puu-xv/2017 Terkait Pembatalan Sanksi Pidana Terhadap Jaksa Penuntut Umum Dalam Penanganan Perkaran Anak Berhadapan Dengan Hukum' (2019) Vol. 2 No. 1 Media Iuris. 
--Halaman ini sengaja dikosongkan-- 